\title{
EFEKTIFITAS LAYANAN BIMBINGAN KELOMPOK DENGAN TEKNIK SELF MANAGEMENT UNTUK MENINGKATKAN KEMAMPUAN MANAGEMEN WAKTU BELAJAR SISWA SMA IT GRANADA SAMARINDA
}

\author{
Dwi Sona, Ulfa Dwi Yanti \\ Universitas Mulawarman Samarinda \\ Email: Dwisona90@yahoo.com
}

\begin{abstract}
Abstrak
Tujuan dari penelitian ini yaitu untuk menganalisis efektifitas dari layanan bimbingan kelompok dengan teknik self management untuk meningkatkan manajemen waktu belajar peserta didik SMA IT Granada Samarinda. Penelitian menggunakan penelitian kualitatif dengan metode deskriptif. Su mber data dari penelitian yaitu dari guru BK, wali kelas, dan peserta didik SMA Granada Samarinda. Teknik pengumpulan data dari penelitian ini yaitu dengan menggunakan wawancara, observasi, dan angket. Teknik analisis data pada penelitian ini yaitu mereduksi data, penyajian data, dan penarikan kesimpulan. Hasil dari penelitian dan analisis dari penelitian ini dapat disimpulkan yaitu, bahwa permasalahan kurangnya kemampuan peserta didik dalam mengelola waktu belajar di rumah ataupun di sekolah tidak efektif dan efisien. Permasalahan kurangnya kemampuan peserta didik untuk memanajemen waktu belajarnya merupakan permasalahan kemandirian, kedisiplinan, dan motivasi dari peserta didik itu sendiri. Kesimpulannya adalah dengan memberikan layanan bimbingan kelompok dengan teknik self management efektif untuk meningkatkan kemampuan peserta didik dalam mengelola waktunya dalam belajar. Saran terhadap permasalahan ini yaitu, guru bimbingan dan konseling agar lebih memperhatikan permasalahan yang seperti ini dan menindak lanjutinya dengan menggunakan layanan bimbingan kelompok dengan teknik self management.
\end{abstract}

Kata Kunci: Efektivitas Bimbingan Kelompok, Teknik Self Management, dan Kemampuan Manajemen Waktu Belajar

\section{PENDAHULUAN}

Kita sering melihat secara kasatmata banyak orang yang terlambat dalam ketepatan waktu meskipun dengan berbagai macam alasan.Waktu sangat penting dalam kehidupan sehari-hari. Setiap orang memiliki waktu yang sama dan tidak dapat diulang maupun diputar kembali. Tidak ada kesempatan lagi untuk menghabiskan waktu sesuka hati dan hanya untuk bersenangsenang, karena waktu tidak bersifat menunggu. 
Setiap peserta didik hendak memiliki kemampuan untuk mengelola waktunya terutama dalam belajar. Manajemen waktu belajar menjadi salah satu jenis permasalahan yang muncul pada peserta didik. Sering kali peserta didik terlalu terlena melakukan halhal yang kurang bermanfaat dan senang menunda-nunda suatu kegiatan, seperti: menunda mengerjakan PR, tidur larut malam karena bermain handphone, waktu belajar yang kurang, dan kegiatan ekskul yang padat. Dengan demikian peserta didik dapat dikatakan telah menyia-nyiakan waktunya dan kurang mampu mengatur serta mengelola waktu belajarnya.

Berdasarkan hasil dari angket dalam manajemen waktu belajar di SMA IT Granada Samarinda, bahwa dari 20 peserta didik terdapat 6 orang peserta didik yang memiliki manajemen waktu belajar yang rendah, dan 14 peserta didik memiliki manajemen waktu belajar yang sedang.

Berdasarkan hasil wawancara dengan guru bimbingan dan konseling peneliti mendapatkan

informasi bahwa peserta didik memiliki kesulitan dalam membagi waktu belajar dengan kegiatan sehari-hari lainnya. Adapun hasil dari observasi yang telah dilakukan, peneliti mendapati bahwa peserta didik masih ada yang terlambat saat masuk ke kelas walaupun pelajaran akan dimulai. Saat guru akan memasuki kelas terlihat beberapa peserta didik masih duduk di luar kelas. Jika semua peserta didik sudah siap dan semua berada di dalam kelas saat pelajaran akan dilaksanakan maka guru tak perlu menunggu lagi untuk memulai pelajaran yang ada.

Dengan demikian peniliti beranggapan bahwa peserta didik masih suka menyia- nyiakan waktu yang ada atau tidak memanfaatkan waktu belajar dengan baik. Bahkan saat melakukan observasi peneliti melihat sejumlah peserta didik terlambat mengumpulkan tugas rumah mereka. Saat di dalam kelas masih ada beberapa peserta didik yang masih asik mengobrol dengan temannya, terlihat juga peserta didik yang masih mengerjakan PR saat di 
dalam kelas, tertidur saat pelajaran berlangsung.

Melihat fenomena yang terjadi di lapangan saat ini sangat memprihatinkan, mengingat peserta didik yang kurang mampu memanajemen waktunya dengan baik terutama memanajemen waktu belajarnya tentu akan memberikan dampak yang negatif jika dibiarkan terus menerus. Dampak dari kurangnya manajemen waktu belajar yang di terapkan

peserta didik saat ini dapat dirasakan oleh peserta didik itu sendiri. yakni peserta didik terlambat mengumpulkan tugas, belajar tidak teratur karena tidak adanya jadwal khusus belajar saat di rumah, tidak siap mengikuti pelajaran saat di sekolah. tentu hal ini akan berdampak buruk bagi peserta didik itu sendiri, oleh karena itu perlu dilakukan suatu upaya.

Guru bimbingan dan konseling merupakan guru yang bertugas membimbing peserta didik agar kemampuan peserta didik dapat berkembang secara optimal. Karena menurut Tohirin (2013: 17) mengatakan bahwa bimbingan dapat diartikan sebagai proses bantuan yang diberikan oleh pembimbing (guru Bimbingan dan Konsling) kepada peserta didik supaya tercapai tingkat perkembangan yang optimal. bimbingan kelompok digunakan agar menghemat waktu dalam pemberian layanan.

Bimbingan kelompok memiliki cara yang unik dalam menyelesaikan kesulitan yang dialami peserta didik. Kelompok yang baik harus dapat menghidupkan dinamika kelompok agar peserta didik saling memberikan bantuan. Dinamika kelompok dapat dihidupkan dengan menyampaikan pendapat dari setiap anggota kelompok. Penyelesaian masalah

\section{METODE PENELITIAN}

Metode yang digunakan dalam penelitian ini adalah penelitian deskriptif dapat dipecahkan memalaui cara berdiskusi. Teknik self management tidak hanya dapat digunakan dalam konseling saja tetapi juga dapat digunakan dalam bimbingan kelompok. Menurut Gerald Corey dalam Linda Ayu 
Lestari (2019: 34) bahwa Self management merupakan serangkaian teknis untuk mengubah perilaku, pikiran, dan perasaan. Teknik self management atau pengarahan diri merupakan upaya individu untuk melakukan perencanaan, pemusatan perhatian, dan evaluasi terhadap aktivitas yang dilakukan. memanfaatkan diskusi dalam dinamika kelompok akan membuat siswa saling bertukar pikiran untuk mengambil keputusan.

Penelitian ini dianggap penting untuk dilakukan karena dapat menambahkan pengetahuan tentang manajemen waktu belajar bagi peserta didik. selain itu Penelitian ini diharapkan dapat meningkatkan kemampuan peserta didik dalam memanajemen waktu belajarnya. Oleh sebab itu penulis tertarik untuk melakukan penelitian tentang "Efektifitas Layanan Bimbingan Kelompok dengan Teknik Self Management untuk Meningkatkan Kemampuan Manajemen Waktu Belajar SMA IT Granada Samarinda Tahun Ajaran 2019/2020".

Penelitian ini memiliki dua variabel yaitu bimbingan kelompok dengan teknik Sel Management sebagai variabel bebas dan manajemen waktu belajar sebagai variabel terikat. Jenis data dalam penelitian ini adalah data primer dan data sekunder. Sumber data didapat dari SMA IT Granada Samarinda dan Guru BK. Teknik pengambilan data dalam penelitian ini adalah observasi, wawancara, dan angket.

Analisis data dalam penelitian ini yaitu reduksi data, penyajian data, dan penarikan kesimpulan. Data tentang kemampuan manajemen waktu belajar dalam penelitian ini dikumpulkan dengan angket yang telah teruji validitas dan reliabilitas perangkatnya.

\section{HASIL PENELITIAN}

\section{Analisi data}

Penyederhanaan

data dilakukan sesuai dengan pernyataan yang singkat namun dapat menggambarkan data relevan yang telah diperoleh. Setelah dilakukan penyederhanaan data dapat ditemukan data yang bermakna sebagai temuan yang disajikan dalam pernyataan singkat tentang hasil 
observasi dan wawancara, masalah saat akan melaksanakan

sedangkan Hasil data angket berdasarkan jumlah responden yang didapatkan yaitu dari SMA IT Granada Samarinda sebanyak 20 peserta didik . Ada 14 siswa yang masuk pada kategori sedang dengan persentase $70 \%$ dan

6 siswa masuk kategori rendah dengan persentase $30 \%$.

\section{PEMBAHASAN}

Melihat dari hasil analisis data bahwa hampir setengah dari responden memiliki kemampuan mengelola waktu belajar yang rendah. Mengelola waktu sangatlah penting terutama dalam belajar. karena dengan mengelola waktu orang dapat dengan mudah menyusun segala aktivitas yang hendak ia lakukan, terutama bagi seorang pelajar. Melihat era saat ini banyak peserta didik yang menganggap bahwa belajar bisa kapan saja, dimana saja, dan sesuai dengan suasana hatinya. Namun belajar tidak seperti itu, saat hendak belajar kita perlu mengatur waktu terlebih dahulu agar tidak menjadi kegiatan yang lain.

Mengatur waktu untuk belajar merupakan permasalahan dalam pendidikan formal. Kenakalan remaja biasa dikenal dalam bahasa latin yaitu Juveniledelinquency yang artinya anak muda yang nakal, jahat, melanggar aturan, pembuat ribut dan lainnya Kartono dalam Triwiyarto (2015: 6).

Menurut Arifin dalam Triwiyarto (2015:

12) faktor kenakalan remaja dibagi menjadi dua yaitu: a. Faktor internal, setiap individu memiliki tingkat emosi yang berbeda-beda. Karena tingkat emosi setiap individu berbeda-beda tentu akan berbeda-beda pula untuk menyelesaikan permasalahan yang sedang dihadapi. b. Faktor eksternal, tentu berasal dari luar diri individu seperti pengaruh dari pergaulan, keluarga, lingkungan, serta kebiasaan hidup. Pergaulan yang salah menjadi penyebab kenakalan remaja, dan menyebabkan terbentuknya pola pikir yang salah. Keluarga juga dapat menyebabkan 
terbentuknya kenakalan remaja, permasalahan dalam keluarga membuat remaja juga ikut merasakan permasalahan yang ada, hal ini tentu setiap remaja menyikapinya dengan cara yang berbeda- beda. Kebiasaan yang buruk tentu akan mempengaruhi pola pikir seorang remaja. berawal dari lingkungan akhirnya mempengaruhi kehidupan sehari-hari. Misalnya ia sudah terbiasa menunda-nunda tugas karena diajak bermain dengan temannya.

Pengelolaan waktu belajar dapat menjadi masalah besar apabila tidak berjalan sesuai dengan yang diharapkan. Terutama dalam penugasan, berdasarkan hasil wawancara dengan guru Bimbingan dan Konseling, dan wali kelas, bahkan dengan peserta didik. Peneliti memiliki pandangan bahwa peserta didik kurang mampu mengelola waktu yang ada. Misalnya, banyak mengeluh mengenai penugasan yang diberikan, peserta didik yang masih mengulur waktu pembelajaran dengan berada di luar kelas, lalu ada juga peserta didik yang terlambat mengumpulkan tugas, terlambat ke sekolah, bahkan keluyuran saat jam pelajaran yang kosong.

Hal ini membuat peneliti memeiliki pemikiran bahwa permasalahan yang sebenarnya ialah kurangnya kemampuan peserta didik dalam mengelola waktu terutama dalam mengelola waktu belajarnya. Lalu peneliti berfifkir bahwa teknik self management ini cocok untuk mengatasi permasalahan ini. Peneliti memiliki pemikiran demikian karena melihat adanya bukti nyata dari penelitian sebelumnya yang menunjukkan adanya pengaruh yang baik dari layanan bimbingan kelompok dengan teknik self management.

Pertama melihat penelitian dari Sindy Elisvi (2018) yang berjudul "Penggunaan Bimbingan Kelompok Untuk Meningkatkan Manajemen Diri Dalam Belajar Pada Kelas VIII SMP IT Nurul Ilmi Aini Bandar Lampung Tahun Pelajaran 2017/2018". Terdapat peningkatan sebesar $21 \%$ terhadap manajemen diri dalam belajar setelah diberikannya layanan bimbingan kelompok. Hasil dari penelitian ini dapat disimpulkan bahwa dengan 
menggunakan layanan bimbingan kelompok dapat meningkatkan manajemen diri dalam belajar.

Kedua melihat penelitian yang dilakukan oleh Masnurima Heriyansah dan Dydik Kurniawan yang berjudul "Bimbingan Kelompok Dengan Teknik Self Management Untuk Meningkatkan Tanggung Jawab Belajar Mahasiswa". Berdasarkan hasil penelitian dapat disimpulkan bahwa bimbingan kelompok dengan teknik self management dapat meningkatkan tanggung jawab belajar mahasiswa. Hal ini telihat dari data tanggung jawab belajar mahasiswa sebelum diberi perlakuan sebesar 31,7\% (kategori rendah) dan data setelah diberi perlakuan diri individu seperti pengaruh dari pergaulan, keluarga, lingkungan, serta kebiasaan hidup. Pergaulan yang salah menjadi penyebab kenakalan remaja, dan menyebabkan terbentuknya pola pikir yang salah. Keluarga juga dapat menyebabkan terbentuknya kenakalan remaja, permasalahan dalam keluarga membuat remaja juga ikut merasakan permasalahan yang ada, hal ini tentu setiap remaja menyikapinya dengan cara yang berbeda- beda. Kebiasaan yang buruk tentu akan mempengaruhi pola pikir seorang remaja. berawal dari lingkungan akhirnya mempengaruhi kehidupan sehari-hari. Misalnya ia sudah terbiasa menunda-nunda tugas karena diajak bermain dengan temannya.

Pengelolaan waktu belajar dapat menjadi masalah besar apabila tidak berjalan sesuai dengan yang diharapkan. Terutama dalam penugasan, berdasarkan hasil wawancara dengan guru Bimbingan dan Konseling, dan wali kelas XI IPS A, bahkan dengan peserta didik. Peneliti memiliki pandangan bahwa peserta didik kurang mampu mengelola waktu yang ada. Misalnya, banyak mengeluh mengenai penugasan yang diberikan, peserta didik yang masih mengulur waktu pembelajaran dengan berada di luar kelas, lalu ada juga peserta didik yang terlambat mengumpulkan tugas, terlambat ke sekolah, bahkan keluyuran saat jam pelajaran yang kosong. 
Hal ini membuat peneliti memeiliki pemikiran bahwa permasalahan yang sebenarnya ialah kurangnya kemampuan peserta didik dalam mengelola waktu terutama dalam mengelola waktu belajarnya. Lalu peneliti berfifkir bahwa teknik self management ini cocok untuk mengatasi permasalahan ini. Peneliti memiliki pemikiran demikian karena melihat adanya bukti nyata dari penelitian sebelumnya yang menunjukkan adanya pengaruh yang baik dari layanan bimbingan kelompok dengan teknik self management.

Pertama melihat penelitian dari Sindy Elisvi (2018) yang berjudul "Penggunaan Bimbingan Kelompok Untuk Meningkatkan Manajemen Diri Dalam Belajar Pada Kelas VIII SMP IT Nurul Ilmi Aini Bandar Lampung Tahun Pelajaran 2017/2018". Terdapat peningkatan sebesar $21 \%$ terhadap manajemen diri dalam belajar setelah diberikannya layanan bimbingan kelompok. Hasil dari penelitian ini dapat disimpulkan bahwa dengan menggunakan layanan bimbingan kelompok dapat meningkatkan manajemen diri dalam belajar.

Kedua melihat penelitian yang dilakukan oleh Masnurima Heriyansah dan Dydik Kurniawan yang berjudul "Bimbingan Kelompok Dengan Teknik Self Management Untuk Meningkatkan Tanggung Jawab Belajar Mahasiswa". Berdasarkan hasil penelitian dapat disimpulkan bahwa bimbingan kelompok dengan teknik self management dapat meningkatkan tanggung jawab belajar mahasiswa. Hal ini telihat dari data tanggung jawab belajar mahasiswa sebelum diberi perlakuan sebesar 31,7\% (kategori rendah) dan data setelah diberi perlakuan sebesar $71,8 \%$ (kategori tinggi). Sehingga terdapat peningkatan sebesar $40,1 \%$ dari data sebelum dan sesudah perlakuan yang diberikan.

Ketiga melihat peneltian yang dilakukan oleh Yossi Putri Novianti (2017) yang Berjudul "Pengaruh Manajemen Waktu Belajar Terhadap Hasil Belajar Siswa Kelas XII IPS Mata Pelajaran Ekonomi MAN Belitar”. Berdasarkan penelitian ini 
dapat disimpulkan bahwa manajemen waktu memilki pengaruh terhadap hasil belajar siswa. Hal ini disebabkan karena dengan adanya pengaturan waktu belajar yang baik maka hasil belajar pada mata pelajaran ekonomi pun juga baik namun jika manajemen waktu belajar yang tidak baik maka hasil belajar ekonomi siswa pun juga rendah.

Maka guru bimbingan dan konseling perlu melakukan treatment yaitu melakukan bimbingan kelompok dengan menggunkan teknik self management. Jika terdapat 6 peserta didik yang memiliki kemampuan manajemen waktu belajar yang rendah maka akan lebih efesien jika memberikan pelayanan secara berkelompok. Jika dilakukan secara berkelompok maka akan menghemat waktu, tenaga, serta biaya untuk memberikan layanan kepada peserta didik. Hal ini tentu akan menjadi hal yang perlu diperhatikan oleh guru bimbingan dan konseling di sekolah tersebut.

Self management atau pengaturan diri pribadi atau diri individu itu sendiri dengan menyesuaikan dengan tujuan yang ingin dicapai. Pengaturan waktu terutama waktu dalam belajar tak bisa diatur dengan sembarangan atau secara asal-asalan saja namun juga perlu menyesuaikan dengan kebutuhan akan kegiatan sehari-hari. Kegiatan setiap individu tentu berbeda- beda. Perlu teknik pengaturan diri sendiriuntuk mengelola waktu belajar agar waktu tidak terbuang secara percuma. Tujuan pengaturan waktu belajar juga agar belajar lebih efektif dan efesien karena tidak lagi terganggu oleh kegiatan yang tidak terencana.

Pemberian layanan bimbingan kelompok dengan teknik self management efektif untuk meningkatkan kemampuan mengelola waktu belajar peserta didik. Hal ini selaras dengan pendapat dari Endang Sri, et al(2010: 12) yang mengatakan bahwa manajemen diri atau self 
management adalah upaya untuk menggerakkan seluruh potensi diri untuk mewujudkan cita- cita dan tujuan hidup secara optimal, sehingga teknik self managemant ini yang memabantu peserta didik untuk mengubah segala perilaku yang dilakukan dengan mengarahkan dirinya ke arah yang lebih baik yang memerlukan upaya atau langkah yang ditempuh untuk mencapai tujuan yang diharapkan serta mengarahkan setiap tindakan seseorang ke hal-hal positif, seperti kemandirian, kedisiplinan, motivasi, dan hubunga dengan orang sekitar yang juga menjadi faktor penting dalam strategi ini untuk mengelola waktu belajar agar waktu tidak terbuang secara percuma. Tujuan pengaturan waktu belajar juga agar belajar lebih efektif dan efesien karena tidak lagi terganggu oleh kegiatan yang tidak terencana.

Pemberian layanan bimbingan kelompok dengan teknik self management efektif untuk meningkatkan kemampuan mengelola waktu belajar peserta didik. Hal ini selaras dengan pendapat dari Endang Sri, et al(2010:

12) yang mengatakan bahwa manajemen diri atau self management

\section{KESIMPULAN}

Berdasarkan hasil dari analisisi data yang telah dilakukan oleh peneliti. Dapat dilihat dari hasil pengolahan data tentang kemampuan peserta didik kelas XI IPS A SMA IT Granada Samarinda bahwa permasalahan yang membuat peserta didik terlambat mengumpulkan tugas, mengeluh saat diberikan tugas oleh guru mata pelajaran, terlambat saat pergi kesekolah, juga terlihat berkluyuran saat jam pelajaran kosong yaitu dikarenakan peserta didik kurang memiliki kemampuan mengelola waktu belajar dengan baik. Kurangnya kemampuan peserta didik dalam mengelola adalah upaya untuk menggerakkan seluruh potensi diri untuk mewujudkan cita- cita dan tujuan hidup secara optimal, sehingga teknik self managemant ini yang memabantu peserta didik untuk mengubah segala perilaku yang dilakukan dengan mengarahkan dirinya ke arah yang lebih baik yang memerlukan upaya atau langkah 
yang ditempuh untuk mencapai tujuan yang diharapkan serta mengarahkan setiap tindakan seseorang ke hal-hal positif, seperti kemandirian, kedisiplinan, motivasi, dan hubunga dengan orang sekitar yang juga menjadi faktor penting dalam strategi ini

waktu belajarnya membuat belajar saat di sekolah maupun di rumah tidak efektif dan efesien. Hal ini tentu menjadi kebiasaan yang buruk jika tidak segera di berikan layanan.

Permasalahan manajemen waktu belajar menurut peneliti merupakan permasalahan pengaturan diri dalam kemandirian, kedisiplinan serta motivasi diri. Untuk hal itu peneliti menganggap bahwa dengan memberikan layanan bimbingan kelompok dengan teknik self management efektif untuk meningkatkan kemampuan manajemen waktu belajar peserta didik SMA IT Granada Samarinda.

\section{REFERENSI}

Astuti, Endang Sri. 2010. Bahan Dasar Untuk Pelayanan Konseling Pada Satuan Pendidikan Menengah Jilid 1. Jakarta : Grasindo
Elisvi, Sindy. 2018. Penggunaan Bimbingan Kelompok

Untuk Meningkatkan

Manajemen Diri Dalam Belajar Pada Kelas VIII Smp IT Nurul Ilmi Aini Bandar Lampung Tahun Pelajaran 2017/2018. Skripsi Universitas Lampung Heriyansah, Masnurima dan Dydik Kurniawan. 2017. Bimbingan Kelompok Dengan Teknik Self Management Untuk Meningkatkan Tanggung Jawab Belajar Mahasiswa. Jurnal Penelitian Pendidikan Indonesia (JPPI). Vol. 2, No. 2

Lestari, Linda Ayu. 2019. Bimbingan Konseling Islam Melalui Teknik Self Management Untuk Meningkatkan Tanggung Jawab Belajar Pada Mahasiswa UIN Sunan Ampel Surabaya. Undergraduate Thesis, UIN Sunan Ampel Surabaya

Putri, Novianti Yossi. 2017. Pengaruh Manajemen Waktu Belajar Terhadap Hasil Belajar Siswa Kelas XII IPS Mata Pelajaran Ekonomi MAN Belitar. Skripsi. Universitas Islam Negeri Maulana Malik Ibrahim Malang

Tohirin. 2013. Bimbingan dan Konseling di Sekolah dan Madrasah (Berbasis Integrasi). Edisi Revisi, Jakarta: Rajawali Pers

Triwiyarto, Uut. 2015. Studi Kasus Tentang Penyebab Kenakalan Remaja. Skripsi Bimbingan dan Konseling. Universitas Sanata Dharma Yogyakarta 